\title{
Only an Academic, or also a Grass-roots Prophetess? The Influential Career of Feminist Theologian Mary-Anne Elizabeth Plaatjies-Van Huffel
}

\author{
David Peter Carelse \\ Uniting Reformed Church in Southern Africa \\ dpcarelse.legal@outlook.com
}

\section{Abstract}

This article celebrates the remarkable life and work of Mary-Anne Elizabeth Plaatjies-Van Huffel as a noted scholar, devoted pastor, and a woman with creative leadership. The article tries to persuade that the generations to come will be empowered by her influential career. Specific attention will be given to her commitment to justice. Her proposals for the transformation of patriarchal anthropology will be explored. This article assesses her insights into the Constitution, relevant legislation, and international human rights instruments. Also, we emphasise how she applied her insights to spell out a vision of a nonsexist and egalitarian society. Attention is given to her contribution to the Reformed Church polity. The article focuses on her work to restore the Doleantie church polity and on her stance regarding the application of labour law and natural law. In conclusion, Plaatjies-Van-Huffel is defined as a pioneer, a leader in ecumenism, and one of Africa's finest feminist theologians.

Keywords: Mary-Anne Elizabeth Plaatjies-Van Huffel; academic; prophetess; patriarchal anthropology; Reformed Church polity; non-sexist; egalitarian; leader in ecumenism

\section{UNISA $\cong$}




\section{Aim and Method}

The aim of this article, written for a Festschrift in honour of Mary-Anne Elizabeth Plaatjies-Van Huffel, is to tell part of her influential story within the church, the academy and society. The telling of this story encompasses four phases. The first phase deals with her life and work since her birth in Prieska in the Northern Cape, until her role as a teacher and an ordained minister. The second phase covers the period 20022010, with a focus on her work as a pastor, Actuarius, and vice-moderator. The third phase covers 2010 to October 2013, her life and work as a lecturer at the Faculty of Theology at the University of Stellenbosch and her involvement in church structures. The fourth phase starts with her election as one of seven vice-presidents of the World Council of Churches (WCC) at its 10th Assembly during 2013, held in Busan, the Republic of Korea.

Regarding the method applied in this article, I have chosen to explore four themes in her life and work, namely: 1) theological anthropology; 2) unity and ecumenism; 3) justice and peace; and 4) African Reformed church polity. These four themes run like a golden thread through the whole of her life, her ministry as a pastor, her publications, and her presentations (academic and non-academic) on a national and international level. In the discussion it will become clear that these four themes interact with each other. The selection is academically orientated and is also the result of my own experience while working with her on various ministries, meetings in the church and at the Faculty of Theology at the University of Stellenbosch. The method will illustrate that her whole life and work was and will always be a narrative that connects faith, Sunday worship and public life. The method will portray her as the roaring lioness ${ }^{1}$ for academic excellence, inclusivity, gender equity, the human flourishing of women, decolonial epistemologies, economic empowerment, and for a feminism of resistance. To do so, the article will mainly concentrate on her writings, the Acts and church orders of synods, and policy documents of the World Council of Churches (WCC). By exploring these documents, this article attempts to appreciate the scope and scale of the influence of a remarkable woman, of an esteemed scholar, an intellectual powerhouse.

The designation of Plaatjies-Van Huffel as prophetess is to examine her life and work in light of the role of Old Testament prophets like Deborah, Miriam, Amos, Micah, Jeremiah, Isaiah, and so forth: she was a prophet who was called not only to proclaim God's word, but to embody and enact that word; the prophet who acted as a model for leadership in the faith community, as one who upheld the claims of those who are exploited and denied dignified living conditions; the prophet who regarded justice and

1 This metaphor of a lioness is taken form the African folklore: When lions go to kill, then it is always the lionesses who are successful in making the kill, and not the male lions. 
equality as theological and juridical terms $;^{2}$ the prophet who was called as representative of God to challenge the dominant economic, social and political consciousness and to provide an alternative consciousness $;{ }^{3}$ the prophet as a person with a message of hope and solidarity in the midst of broken people and broken communities. ${ }^{4}$

I now start with the first phase.

\section{First Phase: From Prieska in the Northern Cape to a Teacher and Ordained Minister}

Mary-Anne Elizabeth Plaatjies was born on 15 December 1959 in the poverty-stricken rural town of Prieska during racist apartheid South Africa. She underwent training at the University of the Western Cape for non-whites, where she qualified as a teacher in 1978. After a successful teaching career, the dedicated and activist teacher returned in 1986 to the same university and commenced her theological studies to become a Minister of the Word and Sacraments (Flaendorp 2014, 53). She knew the then Dutch Reformed Mission Church (DRMC) decided only in 1982 to allow women to the pulpit and that no female proponent had yet been called to a congregation. She was licensed by the Curatorium in November 1991. This first phase saw the first of many pioneering events in her life and work, namely the first women pastor to be ordained. ${ }^{5}$ She started her ministry on 26 November 1992 in the combination congregation of Robertson/Robertson-East (Flaendorp 2014, 54). This congregation is situated in the Boland region of the Western Cape Province. She ministered together with Rev. Jimmy de Wet. After three years, she was the sole pastor of the newly constituted RobertsonEast Congregation until 28 April 2010. I explore below her struggle for justice during this phase.

2 The prophets understood justice (mišp $\overline{\alpha t}$ ) and righteousness (ședeq, masculine; șědōqāh, feminine) as closely associated. Both were preached as aspects of God's character. See Isaiah 5:16; Jeremiah 9:24; Micah 6:8 and Amos 5:24. For a discussion of justice in the prophecies, see Bruce C. Birch, 2006, "Reclaiming prophetic Leadership," Ex Auditu (2): 1-26; Bruce C. Birch, 1995. "Moral Agency, Community, and the Character of God in the Hebrew Bible." Semeia 66: 23-42.

3 See Walter Brueggemann, 1978. The Prophetic Imagination, Philadelphia: Fortress, 1345; Urbaniak, J. 2016. "What Makes Christology in Post-apartheid South Africa Engaged and Prophetic? Comparative Study of Koopman and Maluleke." In Theological Disciplines and the (Post)-apartheid Condition: Genealogies and Future Directions, edited by R.

Venter, Vol. 1, 135-136.

4 See Isaiah 42-55, read with Psalm 137. Recent scholarship on Jesus with His message of hope, healing, and an alternative society, portrays Jesus as a prophet with the use of prophetic themes in his teaching. See for example William Herzog, 2006. Jesus, Justice and the Reign of God. Louisville: Westminster/John Knox.

5 Rev. Dr Nyambura J. Njoroge, WCC Ecumenical HIV and AIDS Initiatives and Advocacy coordinator, who first met Plaatjies-Van Huffel at the WCC 10th Assembly in Busan, expressed her after the passing away of Plaatjies-Van Huffel: "Eventually I got to know that we were pioneers in the ordination of women in our respective churches and in other ways as African women and theologians and ecumenical leaders." See www.oikomene.org, accessed August 1, 2002. 


\section{Justice}

As indicated above, Plaatjies-Van Huffel enrolled for studies at the University of the Western Cape (UWC) during the heyday of apartheid. She was there in the midseventies, especially in the year 1976 when learners and students at schools, universities and technikons protested against unjust political, economic and educational systems. This was the beginning of her role as agent for resistance and as a lioness roaring against any form of injustice. Here already, she manifested herself as a woman with active participation in the processes to transform society. Her struggle against the social, economic, education and political injustices of apartheid started incredibly early. Later in her career she would narrate her experiences of the struggle for socio-political justice during her study years at UWC. Already in her student years, and in her early years in the ministry, she had the imagination of the Belhar Confession that would emerge in her later writings, namely the Confession as a guiding light for social justice issuesespecially racism, inequality, segregation, poverty, domination. Her article "Reading the Belhar Confession as Historical Text" (Plaatjies-Van Huffel 2013c, 10) was later published in the book, Reformed Churches in South Africa and the Struggle for Justice: Remembering 1960-1990. Herein she narrates with imagination the socio-political history of that time, because the "socio-political realities in apartheid South Africa had a bearing on the decisions of the DRMC synod of 1982, which convened in Belhar" (Plaatjies-Van Huffel 2014, 23). The Belhar Confession was drafted in the racially segregated township of Belhar (for so-called coloureds) as one of many semi-urban townships for blacks, Indian and coloured people, constituted by the racist apartheid government. The delegates at the DRMC synod of 1982 were members of a racially segregated church, which had been constituted by the Dutch Reformed Church (DRC) in South Africa. The socio-political history is described by Plaatjies-Van Huffel (2014, $10)$ in the following manner:

The mid-1970s, with the Soweto uprisings as a turning point, overturned just about everything within the DRMC and the DRCA. These churches did not remain untouched by the realities of the day. Hence, from 1974 onwards, both the DRMC and the DRCA put across their disapproval of the system of apartheid. During the 1970s, the communities served by the DRMC and the DRCA became increasingly involved in protesting against and opposing apartheid legislation in all spheres of life. Youth and student revolts resulted in expulsions and detentions, and ultimately some members of the DRMC and the DRCA even went into exile. As a consequence, during the 1980s, the DRMC and the DRCA strongly opposed the way in which the South African 
government used banning and detention without trial, and solitary confinement to silence those who criticised the unjust system of apartheid. [my emphasis] ${ }^{6}$

\section{Anthropology}

In each phase it will become clear that this scholar and pastor engaged on this topic with scholars of different disciplines, for example philosophy, missiology and New Testament. To start with, I want to argue that her enrolment as a student in theology in 1986 was a courageous step and prophetic act to challenge the male-dominated theological anthropology of the then DRMC. She would later, as a theologian, look back on the theological assumptions of the DRMC, the DRC and the DRCA theologians regarding gender injustices. I mention here one of her many well-articulated and wellstructured articles, "Women in the Theological Anthropology of Oom Beyers Naude" (Plaatjies-Van Huffel 2008a, 115). She focuses herein mainly on the theological anthropology in the DRC. It is her submission that their "theological anthropology during the seventies took place mainly from a liberation theology framework, and not from a feminist framework" (Plaatjies-Van Huffel 2008a, 115). She is adamant that although male theologians from the DRC rejected the apartheid ideology, they never challenged the "total theological anthropology responsible for the dominant discourses concerning class, race and sex." Plaatjies-Van Huffel $(2008$ a, 116) finds support in the statement of Denise Ackermann ${ }^{7}$ who writes that "the priority afforded to combat institutionalized racial discrimination during the struggle for liberation, though it is understandable, has unfortunately led to the side-lining of women's issues" (Ackerman 1995, 122 in Plaatjies-Van Huffel (2008a, 117).

In another academic article of an exceedingly high calibre, entitled "About the Empowerment of Women in the Church in Post-apartheid South-Africa: A PostStructural Approach," Plaatjies-Van Huffel $(2008 b$, 115) starts with the following words:

Being a minister of the Uniting Reformed Church in Southern Africa serving a congregation in Robertson-East, a small, rural town in the Western Cape, I have become involved in issues of gender equality and the empowerment of women in the church. It has become clear to me that even though the period since 1994 has been characterised by fundamental policy and legislative reforms which should have impacted women in the church and non-profit organizations (NPOs), the non-compliance with the said policies is still apparent in post-apartheid South-Africa.

6 Her struggle for justice would also be relevant in her later days. See Plaatjies-Van Huffel, Mary-Anne E. 2015, "A Chronology of the Political and Theological Activity at the University of Western Cape during the Heyday of the Struggle against Apartheid," in Umstrittene Beziehungen: Protestantismus zwischen dem südlichen Afrika und Deutschland von den 1930er Jahren bis in die Apartheid Zeit $=$ Contested relations: Protestantism between South Africa and Germany from the 1930s to the apartheid era, edited by Hanns Lessing, Tilman Dedering, Jürgen Kampmann, and Dirk J. Smit. (LIT Verlag).

7 Her source is Ackermann, D. 1995. "Reproductive Rights and the Politics of Transition in South Africa." Journal of Feminist Studies in Religion, 1 (Fall): 117-127. 
With prophetic faithfulness and compassion for the flourishing of women, she explicitly voiced her resistance against the experiences of gender injustices in the Robertson region since her arrival in 1992. Her involvement in church and society made her realise "that even the presence of women in the decision-making structures of the church, school boards, and the like does not necessarily transform the androgen nature of anthropology in the post-apartheid South Africa" (Plaatjies-Van Huffel 2008b, 119). She also objected to the language "used in official documentation of URCSA and even School Board reports." The language, she explains, is not gender-sensitive and is "not a neutral medium but constitutes women as dependent objects in a patriarchal system, portraying them as obedient/dependent and voiceless bodies" (Plaatjies-Van Huffel $2008 \mathrm{~b}, 120)$. The upliftment work spearheaded by this grass-roots prophetess did not go unnoticed. In 2004 she was nominated as a recipient of a Provincial Honours award. Such an award is given to residents who have performed exceptionally or rendered exceptionally meritorious service in the interest of the province. In recognition of her achievements, she received the Premier's Commendation Certificate. ${ }^{8}$ This award was given to her in terms of section 2 of the Western Cape Provincial Honours Act, 1999 (Act 9 of 1999) ${ }^{9}$ for work amongst the impoverished in the Robertson area.

\section{Second Phase 2002-2010: Pastor, Actuarius, Vice-Moderator}

\section{Anthropology}

The drive to deconstruct the dominant male-favoured discourse and to promote the empowerment of women, as illustrated in the first phase above, led to an MTh dissertation in 1998, entitled: "Is die Kerk Middeleeus? 'n Kritiese Studie oor die Geloofs- en Kerklike Praksis m.b.t. Prostitusie in die NGK Familie in die KaapseSkiereiland," at the University of the Western Cape. How dynamic and powerful she could write on this topic is clearly seen from a published article entitled "Vroue in die Teologiese Antropologie van die Afrikaanse Gereformeerde Tradisie" (Women in the Theological Anthropology of the Afrikaans Reformed Tradition) (Plaatjies-Van Huffel and Landman 2005, 203-222). ${ }^{10}$ Written together with her distinguished supervisor, Prof. Christina Landman, this article explores the theological anthropology of the Afrikaans Reformed tradition between 1924 and 2002. This article laments the absence of women in the historiography of the church and society. From the establishment of the synod of the DRMC in October 1881, until its synod assembly in 1924, they found no references to women in the official sources (Plaatjies-Van Huffel and Landman 2005). They argue that the position and status of women was not really part of the theological anthropology of the church. It was only after 1924, they write, that the

8 See Plaatjies-Van Huffel, Mary-Anne E. Curriculum Vitae. http://www.sun.academia.edu. Accessed August 10, 2020.

9 This Act 9 of 1999 is rooted in section 6(1) of the Western Cape Constitution.

10 Plaatjies-Van Huffel and Christina Landman 2005, Studia Historiae Ecclesiasticae XXXI (1) June: 225-246. This article is based on her PhD thesis, "Vroue in die Teologiese Antropologie van die Afrikaanse Gereformeerde tradisie (2003)", University of South Africa. Christina Landman was the promotor and E. van Niekerk the co-promotor. 
churches would put this matter on the agenda. In dealing with the decisions of the synods concerning the rights of women, they found discontinuity, fragmentation and inconsistencies in the historiography. They further write that women of all races have played a significant role in the formation of society and of church institutions; that women have carried the church in more than one aspect, and yet there are only a few women who feature in the historiography of the church and society (Plaatjies-Van Huffel and Landman 2005).

In this article they also express a concern for the fact that gender justice is absent in the early writings - even of prominent theologians like Allan A. Boesak. They do acknowledge that Boesak made a remarkable contribution to the discussion of the relation between black theology and the Reformed identity (Plaatjies-Van Huffel and Landman 2005, 117). Despite this remarkable contribution, they argue that Boesak never put the struggle of women and their yearning for liberation from patriarchy and for social economic empowerment, within the framework of black Reformed identity. Plaatjies-Van Huffel was adamant that not once in his many Bible studies, sermons, public speeches, articles, and publications did Boesak deal with the exclusion of females or marginalisation or the androcentric exegesis that maintains patriarchy. Only in 2005, Plaatjies-Van Huffel asserts, did Boesak in his populist work, Die Vlug van Gods Verbeelding, begin to deconstruct the traditional assumptions of patriarchy in his exploration of the narratives of six women in the Bible and their struggle for justice (Plaatjies-Van Huffel and Landman 2005, 116).

\section{Church Polity}

\section{Restoring the Doleantie Church Polity Principles}

At the synod of 2002, the Uniting Reformed Church in Southern Africa (URCSA) acknowledged the capabilities of this scholar and elected her to the position of Actuarius (church law expert). ${ }^{11}$ She became the first woman to be elected in such a responsible position. It will be clear from the contents of this phase and the next phase that the pastor of Robertson-East congregation had made her mark on church structures formerly occupied exclusively by men, in a decisive manner. It was during this phase and within the Robertson-East congregation that this profound scholar produced her second doctorate, a PhD in church polity, entitled "Die Doleantiekerkreg en die Kerkreg en Kerkregering van die Nederduitse Gereformeerde Sendingkerke en die VGKSA" (2008c) at the University of Pretoria. ${ }^{12}$ The Doleantie church polity goes back to the

11 The duties of an Actuarius, among other things, is to guide the minor and major assemblies or ordinary members in matters like meeting procedures, admonition and discipline, appeals, retirement, and calling of a minister. Also, to advise assemblies in difficult disputes between a pastor and member(s) or a pastor and his/her church council that may lead to lawsuits in a civil court.

12 Plaatjies-Van Huffel published in the same year (2008) an article with the same title. She also touched on these principles in a thought-provoking presentation delivered at the Church Polity Conference 2123 September 2010 at the University of Pretoria: Koffeman se Boek het Goed Recht van de Kerk: A Critical Reflection of Ecumenical Church Polity. 
decisions of the Synod of Dordt. ${ }^{13}$ In Chapter 1 of this seminal work, she discusses with great skill seven church polity principles, namely: 1) the autonomy of the local congregation; 2) Christ as the head of the church; 3) the character of the denominational ties; 4) the power of the major assemblies; 5) the power to discipline church officials; 6) the right to appeal church decisions; and 7) the capability of the major assemblies regarding misconduct. She provides the history of the development of these principles since the ground-breaking work of the Reformer, John Calvin. ${ }^{14}$ She also discusses with great clarity the work of the Netherland lawyer, Johannes Voet (Plaatjies-Van Huffel $2008 \mathrm{c}, 10,11,15) .{ }^{15}$ What I find very useful is her insight that the following notions of Voet are still of great relevance for current church polity: 1) that the power (authority) of major assemblies is delegated power (potesta delegate), while the power (authority) of church councils on the other hand, is original power; 2) that major assemblies may preside over minor assemblies and determine matters of controversy which arise therein; and 3) the term "major" is the equivalent of "broader" and does not indicate a higher rank.

\section{Application of the Doleantie principles in the DRC Family}

A great advantage of her second doctorate is that she illustrates convincingly how the DRC rejected the Doleantie church polity principles as well as the notions of Johannes Voet. The rejection allowed the DRC to ignore the autonomy of the local congregation, the right of a major DRMC assembly to discipline all pastors/elders/deacons, and the right to appeal (Plaatjies-Van Huffel 2008c). She argues very convincingly that the DRC refused that those white DRC pastors who served in the DRMC be disciplined by the DRCM assemblies. The DRC, she continues, also minimised the ecclesiastical powers of the DRMC major assemblies to discipline "by maintaining an overriding jurisdiction that resided in the Mission Commission of the DRC" (Plaatjies-Van Huffel 2008c). This conduct, which was challenged by the DRMC already in 1908 , would only come to an end in 1982 when the DRMC synod adopted a church order consisting of 103 Articles.

Plaatjies-Van Huffel argues that the so-called "daughter churches" of the DRC, namely the former DRMC, the Reformed Church in Africa (RCA), and the Dutch Reformed Church in Africa (DRCA), had placed great emphasis on the principles of the Doleansie church polity since their establishment. She follows the scriptural basis of the church as ecclesia in the New Testament, which term (ecclesia) defines the church as the congregation of believers in a specific location. Essentially, the church is therefore, according to the Doleansie church polity the local congregation of believers. Every local congregation is a complete church (ecclesia completa). The concept of the visible local

13 The Synod of Dordt was held from 13 November 1618 until 29 May 1619 in the town of Dordrecht in the current Netherlands, in the Koveniersdoelen building.

14 Her sources are Calvin, John, 1541. Ecclesiastical Ordinances, in Schaff, 1882, 333-336; Calvin, John, 1559, Institutes of the Christian Religion, two volumes, edited by John T McNeill, translated by Ford Lewis Battless, 1960. Philadelphia, London: The Westminister Press.

15 Her source is Voetius, G. 1888. Kerkregtelike Verhandelingen, translated from De Politica Ecclesiastica van Gysbertus Voetius edited with preface by F. L. Rutgers (Amsterdam: J. A. Wormser). 
church - with the various offices of minister, elder and deacon - is for her the starting point and the foundation of Reformed ecclesiology.

\section{Third Phase 2010-2012: Lecturer at the Faculty and Involvement on National and International Levels}

\section{Unity and Ecumenism}

Flaendorp (2014, 53-63) discusses the life and times of Plaatjies-Van Huffel. He portrays her ecumenism with the description of "a transformative church leader in subSaharan Africa" whose influence stretches "far beyond the confines of the Faculty of Theology." Flaendorp writes that her appointment at the Faculty of Theology at the University of Stellenbosch was realised after many unsuccessful attempts, despite her good "qualification, experience and stature" (Flaendorp 2014, 58). He narrates in a very profound manner that Plaatjies-Van Huffel regarded ecumenism as one of the forces that transformed Women's Ministries (Plaatjies-Van Huffel 2011a) from mere docile objects in the theological discourse to sites of change. What made her a legendary figure and woman of merit, he concludes, is also her role in the unification process between the DRC and URCSA. Flaendorp $(2014,60)$ explains how she was always interested in the importance of "using hermeneutical keys to understand church judicial matters with regard to church unification" between the DRC and URCSA and that she "regarded this issue as her biggest challenge as a theologian and church leader."

\section{Anthropology}

In an innovative article, entitled "Patriarchy as Empire: A Theological Reflection," Plaatjies-Van Huffel (2011c) quotes the words of the then honourable President of the Republic of South Africa, Mr Nelson Rohlihlala Mandela. The president said during his speech at the opening of the South African parliament in Cape Town on 25 May 1994:

It is vitally important that all structures of government, including the president himself, should understand this fully: that freedom cannot be achieved unless women have been emancipated from all forms of oppression. All of us must take this on board, that the objectives of the Reconstruction and Development Programme (RDP) will not have been realized unless we see in visible and practical terms that the condition of the women in our country has radically changed for the better, and that they have been empowered to intervene in all spheres of life as equals with any other member of society.

These words of former President Mandela, Plaatjies-Van Huffel writes, emphasise "the need to engender patriarchal South Africa towards gender equality/equity" (2011c, 2). ${ }^{16}$ Patriarchy is present in the ecclesial as well as in the societal structures and has, she argues, also political and legal dimensions. These dimensions become visible when patriarchy is defined as a type of empire. She describes "empire" as "a patriarchal, top-

16 It needs to be mentioned here that she was for years invited to preach for the Mandela family. See Plaatjies-Van Huffel, Mary-Anne E., 2013f, Sermon for the Family of the late State President Nelson R. Mandela. Sermon at Prayer Meeting at Mandela's Residence in Houghton, 11 December 2013. 
down system that is characterised by a coming together of economic, cultural, political and military power in our world today" (Plaatjies-Van Huffel 2011c, 3). It is a spirit of "lordless domination" which operates on a global level to serve, promote, and defend the "interests of powerful corporations, nations, elites and privileged people." The multi-faceted domination exploits creation. It also "imperiously excludes, enslaves, and even sacrifices humanity." It is the "colonization of consciousness, values and notions of human life" by an imperial mindset (Plaatjies-Van Huffel 2011c, 4). And because patriarchy is a system that "promotes hierarchies and awards economic, political and social power to one group over others," she argues that patriarchy can thus "be rightly defined as empire, as a lordless domination created by mankind."

To promote the transformation of patriarchal anthropology in post-apartheid South Africa, or phrased otherwise, to tackle the lordless empire in South African politics, economy, and culture, she considers applying the Constitution. I am astonished by her creative thought to grasp, as a non-lawyer, the transformative vision in the Final Constitution. ${ }^{17}$ She magnificently understood the purpose of the Constitution to guide the country from a culture of human wrongs to "a culture of human rights." She described the wrongs of the apartheid regime as "institutional racism"; "oppressive"; "blatantly anti-poor, racist and sexist"; "inequalities between class, sex and race"; and "extremely skewed access to employment" (Plaatjies-Van Huffel 2011c, 3). She focuses strongly on ss. 1-3 of the Founding Provisions as well as on the values of (and rights to) equality and human dignity $(\mathrm{ss} 9,10)$ in the Constitution. She describes the mandate of the democracy ushered in on 27 April 1994 as the "mandate of advancing the country towards a democratic, non-racist, non-sexist society." To achieve this, she maintains, the emphasis in post-apartheid South Africa must be "on de-racialisation and the engendering of all institutions towards gender mainstreaming" (Plaatjies-Van Huffel 2011c, 4). "Despite the establishment of a new meaning and culture" through the Constitution and gender policies, she asserts that "the primary form of gender inequalities was maintained" (Plaatjies-Van Huffel 2011c, 3). The answer lies for her in the slow pace of transformation. It is illuminating to see how Plaatjies-Van Huffel, with utmost brilliance, grasped the epistemological truth that the transformation of society is inseparably linked to a transforming legal culture and a transforming theological culture. The phrases "Despite having a Constitution that entrenches equal rights" and "the presence of women in the ecclesial and societal structures is not an indicator of the transformation of the patriarchal anthropology in South Africa," are often recurring

17 The notion of constitutional transformation is remarkably explained in the following: Liebenberg, Sandra, 2008, "Adjudicating Social Rights under a Transformative Constitution," in Social Rights Jurisprudence: Emerging Trends in International and Comparative Law; Davis, D. M., 2010, "Transformation: The Constitutional Promise and Reality." South African Journal on Human Rights 2010: 406; P. Langa, 2006, "Transformative Constitutionalism," Stellenbosch Law Review 351-360; K. Klare, 1998, "Legal Culture and Transformative Constitutionalism," South African Journal on Human Rights 14 (1): 146-188, 150; D. Moseneke, 2002, "The Fourth Braam Fischer Memorial Lecture: Transformative Adjudication." South African Journal on Human Rights (18): 309-319; Davis D. M. and K. Klare, 2017, "Transformative Constitutionalism and the Common and Customary Law," South African Journal on Human Rights 26 (3): 403-509. 
phrases in her writings. ${ }^{18}$ I want to understand it as an influential warning against jurisprudential conservatism and theological conservatism. She read-with a transdisciplinary methodology - the Constitution, relevant legislation, and gender policies from a feminist point of view "to promote gender equality/equity or to transform the patriarchal nature of our society" (Plaatjies-Van Huffel 2011c, 6). Her submission is that the concrete circumstances in which the text of the Constitution applies, may have changed but can by no means considered as being substantively transformed. She motivates:

Notwithstanding the passing of progressive legislation in line with our Constitution and international commitments, real gains in gender equality/equity are still slow to materialise and the engendering of society at large is still lagging behind. Legislative reform has provided the building blocks for a gender equitable society. However, challenges exist in ensuring that these constitutional, legislative and policy imperatives are translated into substantive improvements in engendering the society." (Plaatjies-Van Huffel 2011c7).

She, therefore, laments the suffering still caused by discriminatory practices, structural inequalities, cultural factors, prejudices, patriarchy, violence, sexism, and also continuing unequal power relations between women and men in society, the church and in homes. Women, she continues, "are still scarce on the upper echelons of society." The prophetess, Plaatjies-Van Huffel (2011c, 7), then links transformation unapologetically to the Missio Dei:

Essentially, nothing has changed. ${ }^{19}$ No major paradigm shifts with regard to gendered objects have come to pass. Only a few modifications of the human image have taken place. The root cause of gender injustices lies in the patriarchal structure of our society. ... Legislation is not enough to promote gender equality/equity or to transform the patriarchal nature of our society. In carrying out the mission of God today, we are challenged to transform society intrinsically. The foundational patriarchal, sexist, biased categories of gender analysis should be replaced with new, holistic images.

I now proceed with phase four.

\section{Phase Four: From Busan, Korea 2013 until 2020}

This phase reflects many pioneer achievements. In May 2014, this scholar rose to the rank of associate professor at the Faculty of Theology, University of Stellenbosch. At

18 See Plaatjies-Van Huffel, Mary-Anne E, 2008b, "About the Empowerment of Women in Postapartheid South Africa: A Post-structural Approach."

19 These words of theologian, Plaatjies-Van Huffel, resemble the same sentiment which I find in the feminist jurisprudence of the influential lawyer, Prof. Karin van Marle, at the University of Pretoria, South Africa. She, too, uses the phrase "Nothing has changed again." Van Marle's focus is an alternative jurisprudence. Plaatjies-Van Huffel has an alternative ecclesiology. See Van Marle, K. (ed) 2009. Refusal, Transition and Post-apartheid Law; Van Marle, K. 2003, "Revisiting the Politics of Post-apartheid Constitutional Interpretation.” TSAR (2003). 
the end of 2019, she became the first black woman to be appointed full professor at this Faculty of Theology since its start in 1918. Her election at the WCC Assembly (held from 30 October to 8 November in Busan, Korea) is another pioneering event. ${ }^{20}$ I argue respectfully that this election was indeed a vote of confidence in her leadership potential. Also, that it is a confirmation from the global church that Plaatjies-Van Huffel has excelled as an ecumenical expert who deserves high respect, after all, she was the first woman of Africa to be elected in that position. During this phase she held several other prestigious positions or had membership of important committees at the faculty and university, ${ }^{21}$ of organisations that promote human rights, ${ }^{22}$ and of international ecumenical church organisations. ${ }^{23}$ She spearheaded some of these committees and organisations to enormous success with regard to inter alia transformation, social impact, healing, peacebuilding, and the protection of religious rights and freedoms. Based on her success record she was honoured to be the recipient of the Rector's Award for outstanding research outputs at the University of Stellenbosch. ${ }^{24}$

\section{Justice}

\section{The Pilgrimage of Peace and Justice}

This phase describes the role she played in the embodiment of the Pilgrimage for Peace and Justice of the WCC. ${ }^{25}$ Building on its previous decisions for justice since 1948 in Amsterdam, the WCC 2013 Busan Assembly gathered under the theme "God of life,

20 Prof. Vivian Lavack, the acting Rector and Vice-Chancellor of the University of the Western Cape (UWC), had this to say in her tribute for Plaatjies-Van Huffel as an alumnus of UWC: "Prof. PlaatjiesVan Huffel is described by many as a 'pioneer', a 'glass-ceiling breaker', and a 'trail blazer' who played a remarkable role in her denomination as well as in ecumenical circles nationally and internationally" Posted 1 June 2020. http://www.uwc.ac/za. Accessed August 12, 2020.

21 Program Committee, Community Interaction Committee, Social Impact Committee, Senate Social Impact Committee, Transformation Committee, Faculty Committee, Acting Chair of Social Impact Committee, Acting Chair of Transformation Committee, Acting Departmental Chair. See PlaatjiesVan Huffel Curriculum Vitae, www.sun.edu. Accessed August 10, 2020.

22 International Consortium for Law and Religion Studies (ICLARS) (2013-); Africa Consortium for Law and Religion Studies (ACLARS) (2014-); Church History Society of South Africa (CHSSA) (2012-); South African Council for the Protection and Promotion of Religious Right and Freedoms (SACRRF) (Executive member). See Plaatjies-Van Huffel Curriculum Vitae, www.sun.ed. Accessed August 10, 2020.

23 President of the World Council of Churches (WCC) representing Africa (2013-); Member of the Permanent Committee of Consensus and Collaboration of the WCC (2013-); Member of the Central Committee of the WCC (2013 -); Member of Gender Task Team the World Communion of Reformed Churches 2015-2017; Member of the Procedures Task team of the WCRC. 2015-2017; Member of The Pan African Women's Ecumenical Empowerment Network (PAWEEN). 2017-; Moderator of the Ecumenical Consultation on The Churches Advocacy Role for Children's Right at WCC in Busan, Korea: 30 October 2013 to 10 November 2013; Moderator of Public Issues Committee of the World Communion of Churches (WCRC) at Grand Rapids (18-28 June 2010). See Plaatjies-Van Huffel Curriculum Vitae, www.sun.ed, accessed August 10, 2020.

24 See Plaatjies-Van Huffel Curriculum Vitae, www.sun.ed, accessed August 10, 2020.

25 See WCC Central Committee, 2-8 July 2014, Geneva, Switzerland EN Document No. GEN 05: An Invitation to the Pilgrimage of Justice and Peace. (revised), at 1-7. 
lead us to justice and peace." The assembly issued an invitation to Christians and people of good will everywhere to join in a pilgrimage of justice and peace. As mentioned earlier, it was on this very Busan Assembly that Plaatjies-Van Huffel was elected as a vice-president. Challenged by her experiences in Busan, she took the initiative to commit URCSA and the continent to embody this pilgrimage in every aspect of its mission. Her closing sermon, "Has Christ been divided?" at the General Synodical Commission, 24 November 2013, Umlazi KwaZulu Natal Province, must be seen as her manifesto to take ownership of the pilgrimage. Preaching from 1 Cor. 1:1-17, the now vice-moderator of the WCC, referred to the theme of the Busan Assembly God of life, lead us to justice and peace!" She inspired the meeting with the following words in this sermon:

In a world where the lives of people and the whole of creation are at stake, it is urgent to listen to the word of the God of life. It is vital to discern where and how God is leading God's people to affirm abundance of life for all. So, it is important to study how the people in the Bible responded to the leads and calls by God in their very different contexts and in various ways. Let us pray that we may follow the "God of life" who "leads us to justice, peace and unity" and affirm the fullness of all humanity and creation.

With sincere faith, and leading by example, she guided URCSA to accept the invitation to journey together with the global church and participate in all dimensions of the pilgrimage in a dynamic and creative manner. In her guidance she put emphasis on all three dimensions of the Pilgrimage, namely: 1) Celebrating the Gifts of all partners to the ecumenism; 2) Visiting the Wounds as the result of violence, injustices, suffering, exclusion, discrimination, and a broken creation; 3) Transforming the Injustices. ${ }^{26}$

\section{Ecology and Justice}

Driven by the 1994 policy document, "Justice, Peace and the Integrity of Creation" of URCSA, she became increasingly passionate about caring for the earth. In an article entitled "The Search for a Common Understanding with Regard to Ecology and Justice in the Uniting Reformed Church in Southern Africa" (Plaatjies-Van Huffel 2013d), she engaged with URCSA's responsibility towards God's nature. Her premise is that ecology and justice cannot be separated. In professional fashion and with great clarity the esteemed scholar explores the impact of climate change, ocean change, lack of access to clean water, resource extraction on the impoverished and vulnerable living beings, as well as URCSA's response to hydraulic fracking (Plaatjies-Van Huffel 2013d). At the General Synod Assembly held at Okahandja, Namibia where she was elected as moderator of URCSA, a motion regarding fracking in the Karoo was accepted. She was instrumental in the drafting and acceptance of this proposal. The proposal, which takes Psalm 24:1 as basis, contains brilliance and contextual relevance. It responds to the question of how the church should exercise its dominion and responsibility towards the whole of God's creation. The proposal further guards against

26 See Minutes of the General Synodical Commission (GSC) of URCSA from 2013-2015; Minutes of the General Synod (GS) Executive; Minutes of URCSA General Synod Assembly 2016. 
the economic exploitation of the earth for own interests as well as the possible health damage to people, animals and the whole environment as a result of hydraulic fracturing in the area of the Presbytery of Graaf-Reinet in the Karoo. ${ }^{27}$

\section{The Confession of Belhar as guiding light in the struggle for justice}

During this phase, her writings would constantly link justice issues to the Belhar Confession. ${ }^{28}$ In an article entitled "The Belhar Confession: Born in the Struggle against Apartheid in Southern Africa: A Guiding Light for Today" (Plaatjies-Van Huffel 2013b, 2), she emphasises socio-economic and political justice. The Belhar Confession, she writes, "has its roots in the struggle against apartheid" (Plaatjies-Van Huffel 2013b, 3). Reflecting on current community ills and struggles within URCSA, she is adamant that the Confession has wide implications beyond its original context (Plaatjies-Van Huffel 2013b, 3). She, therefore, uses the Confession "as guiding light in the discourse on race, ethnicity, apartheid, the unification of racially segregated churches and so on, in both the global South and the global North" (Plaatjies-Van Huffel 2013b, 4). Her sense of the imperative to replace injustice with justice is remarkably captured in her statement that apartheid secured and promoted "exclusive privileges for the white section of the population at the expense of the blacks" (Plaatjies-Van Huffel 2013b, 5), and that apartheid created "a situation of injustice and oppression, large-scale deportation to racially segregated group areas and caused havoc to family life and suffering to millions of South Africans" (Plaatjies-Van Huffel 2013b, 5).

\section{Unity and Ecumenism}

\section{DRC and URCSA Re-unification}

Flaendorp $(2014,53)$ discusses the life and times of Plaatjies-Van Huffel, which stretch far beyond the confines of the Faculty of Theology at the University of Stellenbosch. What made her a legendary figure and woman of merit, he concludes, is also her role in the unification process between the DRC and URCSA. He explains how she was always interested in the importance of "using hermeneutical keys to understand church judicial matters with regard to church unification" between the DRC and URCSA, and that she "regarded this issue as her biggest challenge as a theologian and church leader" (Flaendorp 2014, 57).

27 See Decision 185, Acts General Synod of URCSA, 1994. Okanhandja Namibia.

28 See her chapter contribution (Plaatjies-Van Huffel, Mary-Anne E. 2017c), "Acceptance, Adoption, Advocacy, Reception and Protestation: A Chronology of the Belhar Confession." In Belhar Confession. The Embracing Confession of Faith for Church and Society, edited by Mary-Anne E. Plaatjies-Van Huffel and Leepo Modise (Sun Press, 2017), 1-96. 
Her role in the unification process is also seen in the drafting of the Provisional Order. This order has a strong focus on local ecumenism as also on relational ecumenism. ${ }^{29}$ As Moderator of the General Synod she played a pivotal role herein. The Provisional Order was adopted under her leadership at the 2016 Assembly of the General Synod of URCSA, which was held in Benoni, Gauteng. ${ }^{30}$

\section{Global Unity/Ecumenism}

In this phase her ecclesiology would be broadened. Her love for church unity processes must be seen against her love for ecumenism-bringing churches of the Reformed tradition, the Catholic tradition, and other traditions together. This is visible in her duties within the World Communion of Reformed Churches ${ }^{31}$ and her work as Vice-President for Africa of the WCC. Here again, she establishes the link between church, academy, and society. In her well-articulated article "From Conciliar Ecumenism to Transformative Receptive Ecumenism" (Plaatjies-Van Huffel 2017b), she describes ecumenicity as "the second reformation." Ecumenism, she continues, has "hugely influenced the theological praxis and reflection of the church during the past century" [my emphasis].

She encouraged the churches on the continent to shift from mere doctrinal theology to ecumenical theology, from exclusion to embrace, from a mere focus on conversion to a broad vision of social healing and transformation. The emergence of the International Theological Colloquium for Transformative Ecumenism of the WCC, she writes, constituted "a fresh approach in methodology to ecumenical theology and practice." I argue that the ecumenical enthusiasm of Plaatjies-Van Huffel became broader than the previous focus on the DRC family ecumenism. In this phase it has a distinctive global character. It is transformative, relational, empowering, restorative, and healing. It portrays how she articulates ecclesiology as a life-giving ecclesiology (Plaatjies-Van Huffel 2017b, 1-4). She anchors her understanding of transformative ecumenism on the presumption of Kim Yong-Bock from Korea, that the ecumenical movement must contribute to the "idea of a responsible society that is just, participatory and sustainable; and that promotes justice, peace; that protects the integrity of creation" (Plaatjies-Van

29 See for example her paper, "Response on Paper of Prof. CJP (Nelus) Niemandt on Relational Ecumenism: How Ecumenism Changed the Mind and Heart of the Dutch Reformed Church at the 'Ecclesiology and Ethics'." The State of Ecumenical Theology in Africa Conference held on 3-5 June 2015 at UWC.

30 The Provisional Order was negotiated between the DRC, URCSA, RCA and the DRCA during workshops held at Volmoed (Hermanus) and Zikomo (Strand) in the Western Cape in 2015. The Statement of Intent of the Purpose of the Provisional Order is stated as: "The intention of this provisional order is to facilitate and encourage in practical ways our churches, visible reunification at all levels/." Church Order, Stipulations, Regulations, Constitutions of Ministries and Agreements of The URCSA General Synod 2016.

31 Her ecumenical leadership at the WCRC includes: Member of Gender Task Team of the World Communion of Reformed Churches 2015-2017; Member of the Procedures Task team of the WCRC 2015-2017; Moderator of Public Issues Committee of the World Communion of Churches (WCRC) at Grand Rapids (18-28 June 2010). 
Huffel 2017b, 8). Her moderatorship was also influenced and strengthened by the emphasis of Joseeup Keum from Korea, a prominent missiologist and extraordinary professor at the Faculty of Theology at the University of Stellenbosch. His theory that transformative ecumenism must be understood as "a life-centred understanding of the oikoumene" which embraces all of God's creation and that which will "bring transformative spirituality and mission to the heart of the ecumenical movement" (Plaatjies-Van Huffel 2017b, 8). So, too, does she apply the assumptions of Maria Aránzuza Aguado, ${ }^{32}$ especially Aguado's premise that spirituality must serve both "as a basic pillar in the journey towards unity" and as a new vision for the ecumenical movement "to transform God's world." Plaatjies-Van Huffel (2017b, 9) then concludes, once again as a prophetess who speaks up ethically for a shalom life for everybody:

Transformative Ecumenism should therefore be an ecumenism that is rooted in the people's struggle for justice and life, an ecumenism that envisions not only the unity of the church like in conciliar ecumenism. Rather, Transformative Ecumenism focuses on the unity of whole humanity and creation ... that is life-giving and justice-centred ... to reshape the leadership out of moral bankruptcy of ecclesiastical leadership.

The prophetess never forgot that she was vice-president for her continent, for Africa. She dreamed and consciously worked towards an African transformative ecumenism. I deal with this dream of her in the immediate paragraph hereunder.

\section{An African Transformative Ecumenism}

As the WCC vice-moderator for Africa, Plaatjies-Van Huffel accepted the notion of transformative ecumenism as part of her theological tools "to rejuvenate, redefine and reshape African ecumenism and to move forward to an African transformative receptive ecumenism" (Plaatjies-Van Huffel 2017b, 10). Firstly, she encourages scholars of the continent "to utilize their religious, cultural, social, economic, and ethnic conditions as primary research topics." This must be done with a broad focus to influence not only the Africa discourse, but also "the ecumenical discourse globally." And secondly, on a practical and contextual level, she urges that an "African Transformative Receptive Ecumenism" approach must creatively attend to and combat the broad spectrum of issues. In the naming of the issues, we hear her compassion for those who suffer; for those who are marginalised in Africa. She mentions issues such as HIV and/or AIDS, "poverty, racism, tribalism, culturalism, modernism, secularism, sexism, human trafficking, health, education, gender-based violence, climate change, economic

32 Her sources are: Kim, Y. B. 1998, "Civil Society: Unity and Oikos (the House of God)," accessed February 17, 2016, https://www.religion-online.org/showarticle.asp?title; Kim, Y. B., (ed), 2014, "Concept Paper of the Manilla International Theological Colloquium for Transformative Ecumenism 2014," accessed February 17, 2016, https://www.miraeforum.org/category/Colloquium; Kim, Y. B. (ed), 2016, "Growing Together in Transformative Ecumenism, 3rd International Theological Colloquium for Transformative Ecumenism," Lutheran Hotel, Moshi, 1-5; Keum, J., 2008, "Editorial," International Review of Mission 97(384/385): 5; Aguado, M. A. 2009, "Transformative Spirituality and Mission: An Ecumenical Project," International Review of Mission 98 (2): 218-231. 
injustice, corruption, religious conflicts, homophobia, xenophobia, refugees and asylum seekers, statelessness, the legacy of apartheid, and the legacy of the 1994 genocide in Rwanda" (Plaatjies-Van Huffel 2017b, 10). In this article, she gives recognition to black feminist theologians like Isabel Phiri ${ }^{33}$ and black theology theologians like Kwame Bediako, ${ }^{34}$ Tinyiko Sam Maluleke, ${ }^{35}$ and Benezet Bujo. ${ }^{36}$ She also gives special recognition to the work of the "Circle of Concerned African Women Theologians," especially the enormous contribution of Mercy Amba Oduyoye. ${ }^{37}$ The reason for their theology is, among others, to promote the adage "The time has come for Africa to drink from her own wells." As a daughter of Africa, the grassroots-orientated pastor, PlaatjiesVan Huffel, drank from the wells of Africa.

An event of great importance in her career as vice-moderator of the WCC, was the Third International Theological Colloquium for Transformative Ecumenism with the theme "Growing Together in Transformative Ecumenism." The colloquium was held from 11 to 16 January 2016 on African soil in Moshi, Tanzania. The aim of the colloquium, she asserts, was "to extend the vision of Transformative Ecumenism into the African context in order to rejuvenate movement, to redefine ecumenism and to reshape leadership in the continent" (Plaatjies-Van Huffel 2017b, 10-11). Her goals for transformative ecumenism for the continent are: 1) it must be rooted in the people's struggle for justice and life; 2) it should envision not only the unity of the church but also the unity of whole humanity and creation; and 3) it must be driven by passionate and issue-oriented leaders who can clearly stand with suffering and the struggling people (Plaatjies-Van Huffel 2017b, 11).

It is, therefore, quite understandable that bishop Olav Fykse Tveit, the General Secretary of the WCC, paid tribute to her in this remarkable way:

She represented a strong combination of academic theological competence, experience from church leadership, and ecumenical commitment to unity, justice, and peace. She represented African women well as theologian, church leader and ecumenist, and

33 Her source is Phiri, I. A., 1997, "Presbyterianism and Patriarchy: Religious Experience of Chewa Women in Central Malawi," Kachere Series, Zomba.

34 Her sources are Bediako, K., 1990, "Jesus in African Culture: A Ghanaian Perspective" (Accra: Asempa Publishers). Bediako, K., 1996, "Five Theses on the Significance of Modern African Christianity: A Manifesto," Transformation 13 (1): 20-21.

35 Her sources are Maluleke, T. S., 1996, "Black and African Theologies in the New World Order: A Time to Drink from our own Wells," Journal of Theology for Southern Africa 96: 3-19; Maluleke, T. S., 1997, "Half a Century of African Christian Theologies Elements of the Emerging Agenda for the Twenty-first Century," Journal of Theology for Southern Africa 99: 4-23.

36 Her source is Bujo, B., 1992, "African Theology in its Social Context," translated by J. O'Donohue, Concept paper of Seoul International Theological Colloquium for Transformative Ecumenism 2013, Orbis, Maryknoll, accessed February 17, 2016, https://www.miraeforum.org/category/Colloquium.

37 Her source is Oduyoye, M. A., 1995, "Christianity and African Culture," International Review of Mission 84 (332/333): 77-90. Oduyoye established the Circle in 1987. She created it as a space for female theologians of all Christian denominations to express their thoughts academically. Later they also extended membership to women of all religions. 
inspired many to use their gifts and talents in the service of others and the mission and prophetic task of the church. Her faith and love will remain an inspiration to many. I give thanks to the God of life for her all that she gave to us in the ecumenical movement. ${ }^{38}$

\section{Anthropology}

An interesting achievement in this phase is her appointment as head of the Unit for Law and Religion. ${ }^{39}$ Her articulation of anthropology will, from now on, be discussed within theology, jurisprudence, and human rights. I want to compare the vision of PlaatjiesVan Huffel with the notion of imagination in the theology of Rubem Azevedo Alves. He is a Brazilian theologian, philosopher and educator (15 September 1933-July 2014). In his 1972 book, Tomorrow's Child: Imagination, Creativity and the Rebirth of Culture, Alves writes about people who can see a new tomorrow, who can imagine new possibilities that others cannot imagine. They create a new tomorrow by challenging the dominant traditional culture. Therefore, such a person is "Tomorrow's Child." PlaatjiesVan Huffel was Tomorrow's Child. Plaatjies-Van Huffel, the "visionary leader," to borrow the phrase of Flaendorp (2014), imagined trans-disciplinary research at academic and church level. Her activities went more often beyond the borders of mere theology epistemology. Such a broad imagination is evident in her article entitled, "A Response to Anne-Claire Mulder's 'Empowering Those Who Suffer Domestic Violence: The Necessity of a Different Theological Imagery"' (Plaatjies-Van Huffel 2013e). Her focus in this article is on fragile dignity. She illuminates the interaction between theology and the jurisprudence contained in international human rights instruments $^{40}$ as well as legislation of our country. ${ }^{41}$ She applauds once again the transformative vision in the country's Constitution. ${ }^{42}$ Her scope is wide: farm murders, land reform, shelter and housing, rape, domestic violence, refugees. The victims, she writes, are mostly women, girls, and children. They are "in danger in the primary sphere where they should be the recipients of love, security, and shelter" (Plaatjies-Van Huffel 2013e, 224). These crimes, she asserts "constitutes one of the most pervasive forms of human rights violations" and a direct ignoring of "human dignity" (Plaatjies-Van Huffel

38 https://www.oikoumene.org. Accessed on August 1, 2010.

39 The Unit for Law and Religion is an inter-religious and interdisciplinary research, teaching and service division of the University of Stellenbosch. It resides within the Faculty of Theology of this University under the management of the Beyers-Naude Centre for Public Theology.

40 The Convention on the Elimination of All Forms of Discrimination Against Women (CEDAW) (1979); the Convention on the Rights of the Child (CRC) (1989); and the United Nations' Declaration on the Elimination of Violence against Women (DEVAW) (1993).

41 The Employment Equity Act, Human Rights Commission Act (1994); Commission on Gender Equality Act (1996); Basic Conditions of Employment Act (1997); and the Employment Equity Act (1998); the South African National Policy Framework for Women's Empowerment and Gender Equality. All of these, she argues, emphasise the importance of human dignity.

42 Constitution of the Republic of South Africa, Act 108 of 1996. She puts emphasis on section 10 in the Bill of Rights which reads: "Everyone has inherent dignity and the right to have their dignity respected and protected." Human dignity is both a value and a right as defined in sections 1(a) and 7(1) of the Constitution. 
2013e, 225). I find it useful how she applies the Universal Declaration of Human Rights adopted in 1948, to defend the "inherent dignity" and "equal and inalienable rights" and the "right to life, liberty and security of persons." Also, how she powerfully interprets the provisions in international instruments to defend "the fundamental rights and dignity specifically of women and children" and to call on every citizen to eliminate genderbased violence. Plaatjies-Van Huffel's (2013e, 225) submission is:

... the protection of the vulnerable against domestic violence is not only a legal, but also a health, economic, educational, and developmental issue. It is also a human dignity issue, and, for Christians and the Christian church, it should also be an issue of faith. In addition, the discourse on domestic violence is characteristically sexist and biologicalessentialist in nature.... These biological-essentialist conceptual categories and the patriarchal anthropology behind it need to be deconstructed. We need alternative constructions of masculinity, gender, and identity that can foster non-violence and gender justice.

\section{Church Polity}

\section{Revisiting Church Polity Principles}

I have discussed in phase three her excellent exploration of the seven principles of Reformed Church polity. In a thought-provoking article, titled "The Relevance of Reformed Church Polity Principles: Revisiting the Concept," Plaatjies-Van Huffel (2014) revisits these principles with the aim to ascertain:

... whether these principles have been sufficiently incorporated in the church polity of the church of which I am a member, namely, the Uniting Reformed Church in Southern Africa (Plaatjies-Van Huffel 2014, 2).

She makes a diagnostic remark, and in my view as former Actuarius quite correct, that during the past decades "a deviation of the above-mentioned principles took place in URCSA" (Plaatjies-Van Huffel 2014, 2). One example she mentions is that "the major assemblies of URCSA gradually usurped power in order to make decisions on such matters as church unification, property rights and even the confessional basis of the church without giving the minor assemblies the opportunity to participate in the decision-making process" (Plaatjies-Van Huffel 2014, 4). Another example is that URCSA neglected the Reformed Church polity principle that gives "major assemblies in case of maladministration, impuissance, heresy or schism the right to intervene in the governance of the local congregation and to implement their decisions in minor assemblies" (Plaatjies-Van Huffel 2014, 5). She advises that the major meetings should have the authority, if informed of such "neglects, omissions, or irregularities on the part of the minor assembly, to require the latter to produce its records." Also, she asserts that the major meetings should have authority "either to proceed to examine and decide the entire matter as completely as if proper record had been made, or it shall cite the lower meeting and proceed as in the next preceding section" (Plaatjies-Van Huffel 2014). She is adamant that the major assembly must take proper action "in order to preserve the 
purity, peace and good order of the church." Church polity principles, she argues, are essential "for the development of good church governance practices" (Plaatjies-Van Huffel 2014).

Plaatjies-Van Huffel, together with Leepo J. Modise, Motlalentwa G. Betha and others, must be praised for the brilliance with which they safeguarded the Doleantie church polity principles in the Memorandum of Agreement between the DRC and URCSAespecially the ecclesia completa principle. They drafted it carefully in section 3.3 (the local congregation is the expression of the church of Christ in a local community); in section 3.4 (the local churches can express their unity with each); in section 3.5 (the right of the local congregation to participate in decision-making; obtain the permission of congregations). ${ }^{43}$

\section{Linking Church Polity to Natural Law and Labour Law}

In numerous articles the esteemed Plaatjies-Van Huffel surpassed herself in the way she engaged with legal notions and jurisprudence. She has shown an excellent capability to speak nationally and internationally, or publish on the basic tenets of labour law legislation, as well as on the principles of natural justice and the application of natural law in church discipline and appeal procedures. ${ }^{44}$ She deals excellently with jurisprudence and shows that it is essential for the development of good church governance practices, the management of ecclesiastical property, and to maintain sound relations between the pastor and the congregation/presbytery. Her description of the legal structure of URCSA as a voluntary association in terms of the common law, having legal personality (universitas), is to be applauded (Plaatjies-Van Huffel 2011b, 3, 10; Plaatjies-Van Huffel 2013a, 11). What I further find of great significance is her advice that provision should be made in the church order of URCSA on the application of Labour Law on employment relations in URCSA (Plaatjies-Van Huffel 2013a, 112). She further proposed, with good motivation, that URCSA congregations should follow the Employment Equity Act (1998) to promote "equal opportunity in the workplace by eliminating unfair discrimination in any employment policy or practice" (Plaatjies-Van Huffel 2013a, 12).

\section{URCSA's Church Polity gives Pre-eminence to Doctrine}

Plaatjies-Van Huffel is serious about the correlation between worship (liturgy), doctrine (confessions), and public life (deeds). She explores this correlation in her article, entitled "Rethinking the Reciprocity between lex credendi, lex orandi and lex vivendi: As we Believe, so we Worship. As we Worship, so we Live" (Plaatjies-Van Huffel 2020, 12). She traces the history of this axiom back to Prosper Aquitaine. He was a student of

43 For the full text of the Memorandum of Agreement, see General Synod Church Order 2016, 142-147.

44 Plaatjies-Van Huffel, 2017a, "Natural Law in the Reformed Tradition," in Christianity and Natural Law: An Introduction, edited by Norman Doe (Cambridge University Press. University of Cambridge). doi:10.1017/9781316890615; URCSA's engagement on legal matters in South Africa NGTT 54 Supplement 4, 2013: 101-113. http://ngtt.journals.ac.za/pub/article/view/294. 
St Augustine of Hippo (Plaatjies-Van Huffel 2020, 2). In his writing Capitula Coelestini, Prosper used the axiom ut legem credendi lex statuat supplicandi, which means "the law of prayer determines the law of belief." He used the equivalent term lex supplicandii in place of lex orandi (Plaatjies-Van Huffel 2020, 2). Plaatjies-Van Huffel mentions that some theologians follow the example of Prosper and give priority to lex orandi. ${ }^{45}$ Being in the Reformed tradition, she suggests that we must give pre-eminence to doctrine over worship. She argues that this is the characteristic of Protestantism. Committed to Protestantism and the African Reformed Church polity, Plaatjies-Van Huffel $(2020,7)$ maintains:

A Protestant order would be lex credendi, lex orandi, lex vivendi. Protestants usually emphasise the triad of worship, doctrine, and life. Wainwright influenced until this day hugely the discourse in Protestant circles on lex orandi, lex credendi. The core of Wainwright's theological work and Protestantism ordinarily underscores the preeminence of doctrine over the liturgy.

After laying the basis of this adage she does something quite extraordinary, which is in my view a sign of her creative thought. The distinguished professor Plaatjes-Van Huffel $(2020,5)$ tests the church polity of URCSA about this adage. With reference to the Dutch church polity expert, Dingemans (1992, 215 in Plaatjies-Van Huffel 2020, 6,7), she argues very convincingly that a "church order is theology put into practice and translating ecclesiology into church judicial rules and stipulations" (Plaatjies-Van Huffel 2020, 6-7). What a denomination thinks about her identity, or form and structure, or position in the world and its functioning in the community "is being expressed in the church order in legal terminology" (Plaatjies-Van Huffel 2020, 7). Plaatjies-Van Huffel thus finds it necessary to look at how the axiom lex credendi, lex orandi, lex vivendi prevails in one way or another in the church order of URCSA.

Her submission is that the 12 articles of the church order of URCSA start with ecclesiology, with a description of URCSA as part of the una sancta catholica. In Articles 1 and 2 of URCSA's church order she finds URCSA's doctrine, because it contains, among others, the confessions in which URCSA believes (Plaatjies-Van Huffel 2020, 7). Articles 1 and 2, she argues, reflect ecclesiology, the lex credendi of

45 King, K., 2014, "Lex orandi, lex credendi: Worship and doctrine in Revelation 4-5," Scottish Journal of Theology 67 (01): 33-49. https://doi.org/10.1017/S00369306 13000318. In this article, King makes a study of Revelation 4-5 and then summarises: "The ancient principle of lex orandi, lex credendi, coined by Prosper of Aquitaine, gives a further theological foundation for such explorations. However, its later distortion, particularly in the aftermath of the Reformation, has privileged doctrine (credendi) over experience (orandi), and diminished the reciprocity between the two demanded by classical formulation," 33. 
URCSA. ${ }^{46}$ She asserts in a profound scholarly manner that Article 4 starts with the worship (lex orandi) and also has the sending out of the faithful, their service in the world (lex vivendi) ${ }^{47}$ Article 5 connects the worship/liturgy to daily life in the public domain; the lex orandi nourishes and prepares worshippers for their lex vivendi. Here, once again, we see Plaatjies-Van Huffel as the grassroots prophet. Reformed spirituality, she asserts by following Ion Bra, ${ }^{48}$ "should unfold not only in the worship services" and the church meetings, but should also unfold amidst "the people in the squatter camps, in the streets of the cities, the homeless, the refugees, the strangers in our midst." Lex vivendi is also structured in Article 12 of the church order of URCSA because this article defines the church's public relationships and responsibilities.

Plaatjies-Van Huffel then argues that the pre-eminence of this lex credendi, as the confessional basis of URCSA, must shape the worship as well as URCSA's engagement with socio-economic issues and of denomination (Plaatjies-Van Huffel 2020,3). Her conviction is that what we believe and how we worship should be consistent with how we live or live together as disciples of Jesus Christ. Linking church polity to the process of re-unification with the DRC, implies for her that the worship of URCSA should reflect "a resolute commitment to dismantle the apartheid structures, the racially segregated churches in South Africa inherited from Dutch Reformed Church mission history" (Plaatjies-Van Huffel 2020, 8). ${ }^{49}$

\section{Conclusion}

This article celebrates the contributions of Plaatjies-Van Huffel in the fields of justice, unity, and ecumenism, fighting patriarchy, and church polity. The article has illustrated that she excelled to heights no woman pastor or even male pastor in URCSA had reached before. Through the dissemination of her high-quality articles and presentations, she empowered and healed. The skilled professor of church history

46 See Article 2.2: "The Uniting Reformed Church in Southern Africa accepts the ecumenical creeds viz the Apostles' Creed, the Nicene and Athanasian Creeds, and by virtue of its own origins believes that the Confession Belgica (Netherlands Confession of Faith), the Heidelberg Catechism and the Canons of Dordt, as handed down in history, give pure expression to its faith. It furthermore accepts the Belhar Confession (1986), as demanded of the church in the Southern African situation" (URCSA 2016, General Synod Church Order).

47 See Art. 4.2: "Service of God has a bearing on the whole life of the congregation and therefore includes service to one another and the world. The essence of this service of God is found where the congregation meets round the Word of God and the sacraments. There God is worshipped and praised, his Word listened to, the sacraments received, and all needs brought before him in order to strengthen the believers in their faith and to prepare them for their service to one another and the world." $G S$ Church Order of URCSA 2016.

48 Her source is Bria, I., 1996, The Liturgy after the Liturgy. Mission and Witness from an Orthodox Perspective, WCC Publications, Geneva.

49 Plaatjies-Van Huffel displays here practical wisdom, in-depth knowledge of church history as well as authentic systematic theology because it was exactly the distorted lex credendi of the DRC that influence their worship services (lex orandi) in 1857 and since then caused the DRC to have a lex vivendi of separate development and political correctness. 
forever changed the history of URCSA and the ecumenical church. She loved her Creator, with whom all things are possible. The philosopher, John D. Caputo, describes a believer as "a hyper-realist, a believer in love with the impossible and who did not rest until the impossible happens." ${ }^{" 50}$ I argue that Plaatjies-van Huffel fits this description. Therefore, she lived her faith as the hope for a transforming future. She incarnated the God who takes a stand with those who suffer in Robertson, Mamelodi, Scottsdene, Okahandja, Busan, Khayelitsha, the continent and in the global world. The aim of the article was also to show that she became the voice and form of the God who expresses divine solidarity and who replaces stories of unjust and unwanted suffering with stories (narratives) of healing and liberation (John 5:37; Exod. 3:7-9; Philip. 2:2-11). URCSA is challenged to put events in place that will ensure that the voice of the courageous lioness will continue to roar against patriarchy as empire and abuse of power in ecclesial and societal structures, which cause suffering; to promote preference for the lex credendi, especially in the reunification processes.

The various ministries will miss the pastor who attended their meetings and multicultural gatherings; the humble academic who led them joyfully in dance on the beat of "Noyo na, Noyo na." She led them like the prophetess Miriam did (Exodus 3). Her beloved husband, Rev. Dawid van Huffel, and family members can be proud of her legacy that will continue to inspire. Glory to God who gave this amazing gift to us. She must be remembered as a transforming disciple of Jesus Christ, as one of Africa's finest feminist theologians. She refused to be a traditional intellectual leader. Instead, she chose to be and performed magnificently as an organic intellectual leader par excellence, who always challenged the cultural hegemony and worked towards sustainable empowering of learning environments. ${ }^{51}$ Mary-Anne, the amazing gift, who always entertained us with her distinctive smile or laughing while she imitates Gustav Bam's wise words: your life must always be congruent with your faith. She deserves the words in Daniel 12:3: "Those who are wise will shine like the brightness of the heavens, and those who lead many to righteousness, like the stars for ever and ever."

\section{References}

Ackermann, D. 1995. "Reproductive Rights and the Politics of Transition in South Africa." Journal of Feminist Studies in Religion 1 (Fall): 117-127.

Aguado, M. A. 2009. "Transformative Spirituality and Mission: An Ecumenical Project." International Review of Mission 98 (2): 218-231. https://doi.org/10.1111/j.17586631.2009.00018.x.

Alves, Rubem Azevedo. 1972. Tomorrow's Child: Imagination, Creativity and the Rebirth of Culture.

50 Caputo, John D. 2015. Hoping against Hope: Confessions of a Post-modern Pilgrim.

51 I am indebted to the Italian writer Antonio Gramsci (22 January 1891-April 1937) for the two types of intellectuals, namely traditional intellectual and organic intellectual leaders. 
Bediako, K. 1990. "Jesus in African Culture: A Ghanaian Perspective.” Accra: Asempa Publishers. https://doi.org/10.1177/026537889601300104.

Bediako, K. 1996. "Five Theses on the Significance of Modern African Christianity: A Manifesto.” Transformation 13 (1): 20-21.

Birch, Bruce C. 1995. "Moral Agency, Community, and the Character of God in the Hebrew Bible." Semeia 66: 23-42.

Birch, Bruce C. 2006. "Reclaiming Prophetic Leadership.” Ex Auditu (22): 1-26.

Bria, I. 1996. The Liturgy after the Liturgy. Mission and Witness from an Orthodox Perspective. Geneva: WCC Publications.

Brueggemann, Walter. 1978. The Prophetic Imagination. Philadelphia: Fortress, 13-45.

Bujo, B. 1992. "African Theology in its Social Context," translated by J. O’Donohue. Concept paper of Seoul International Theological Colloquium for Transformative Ecumenism 2013. Orbis, Maryknoll. Accessed February 17, 2016. https://www.miraeforum.org/category/Colloquium.

Calvin, John. 1541. Ecclesiastical Ordinances, in Schaff 1882, 333-336.

Calvin, John. 1559. Institutes of the Christian Religion, two volumes, edited by John T McNeill, translated by Ford Lewis Battless, 1960. Philadelphia, London: The Westminster Press.

Caputo, John D. 2015. Hoping against Hope: Confessions of a Post-modern Pilgrim. https://doi.org/10.2307/j.ctt155j2ts.

Constitution of the Republic of South Africa, Act 108 of 1996.

Davis, D. M. 2010. "Transformation: The Constitutional Promise and Reality." South African Journal on Human Rights: 406.

Davis D. M., and K. Klare. 2017. "Transformative Constitutionalism and the Common and Customary Law." South African Journal on Human Rights 26 (3): 403-509. https://doi.org/10.1080/19962126.2010.11864997.

Doe, N. (ed). 2017. "Natural Law in the Reformed Tradition." In Christianity and Natural Law: An Introduction. University of Cambridge. Cambridge University Press. https://doi.org/10.1017/9781316890615.

Flaendorp, C. 2014. "The Life and Times of Professor Mary-Anne Plaatjies-Van Huffel: A Transformative Church Leader in Sub-Saharan Africa." Studia Historiae Ecclesiasticae 40 (August Supplement): 53-66. 
Herzog, William. 2006. Jesus, Justice and the Reign of God. Louisville: Westminster/John Knox.

Keum, J. 2008. “Editorial.” International Review of Mission 97 (384/385): 5. https://doi.org/10.1111/j.1758-6631.2008.tb00622.x.

Kim, Y. B. 1998. "Civil Society: Unity and Oikos (the House of God).” Accessed February 17, 2016. https://www.religion-online.org/showarticle.asp?title.

Kim, Y. B. (ed). 2014. “Concept Paper of the Manilla International Theological Colloquium for Transformative Ecumenism 2014.” Accessed February 17, 2016. https://www.miraeforum.org/category/Colloquium.

Kim, Y. B. (ed). 2016. "Growing Together in Transformative Ecumenism, 3rd International Theological Colloquium for Transformative Ecumenism.” Lutheran Hotel, Moshi, 1-5.

King, K. 2014. "Lex orandi, lex credendi: Worship and doctrine in Revelation 4-5." Scottish Journal of Theology 67 (01): 33-49. https://doi.org/10.1017/S0036930613000318.

Klare, K. 1998, "Legal Culture and Transformative Constitutionalism." South African Journal on Human Rights 14 (1): 146-188, 150. https://doi.org/10.1080/02587203.1998.11834974.

Langa, P. 2006. “Transformative Constitutionalism,” Stellenbosch Law Review 351-360.

Liebenberg, Sandra. 2008. "Adjudicating Social Rights under a Transformative Constitution." In Social Rights Jurisprudence: Emerging Trends in International and Comparative Law.

Maluleke, T. S. 1996. "Black and African Theologies in the New World Order: A Time to Drink from our own Wells.” Journal of Theology for Southern Africa 96: 3-19.

Maluleke, T. S. 1997. "Half a Century of African Christian Theologies Elements of the Emerging Agenda for the Twenty-first Century." Journal of Theology for Southern Africa 99: 4-23.

Moseneke, D. 2002. "The Fourth Braam Fischer Memorial Lecture: Transformative Adjudication." South African Journal on Human Rights (18): 309-319. https://doi.org/10.1080/02587203.2002.11827648.

Oduyoye, M. A. 1995. "Christianity and African Culture." International Review of Mission 84 (332/333): 77-90. https://doi.org/10.1111/j.1758-6631.1995.tb02690.x.

Phiri, I. A. 1997. "Presbyterianism and Patriarchy: Religious Experience of Chewa Women in Central Malawi.” Kachere Series, Zomba.

Plaatjies-Van Huffel, Mary-Anne E. Curriculum Vitae. http://www.sun.academia.edu. Accessed August 10, 2020. 
Plaatjies-Van Huffel, Mary-Anne E., and Christina Landman. 2005. "Vroue in die Teologiese Antropologie in die Afrikaanse Gereformeerde Tradisie." Studia Historiae Ecclesiasticae 31 (1): 203-222. http://uir.unisa.ac.za/handle/10500/4367.

Plaatjies-Van Huffel Mary-Anne E. 2008a. "Women in the Theological Anthropology of Oom Beyers Naude.” In Oom Bey for the Future. Beyers Naude Centre Series on Public Theology Stellenbosch: SUN Press.

Plaatjies-Van Huffel, Mary-Anne E. 2008b. "About the Empowerment of Women in Postapartheid South Africa: A Post-structural Approach.” In From our Side Emerging Perspectives on Development and Ethics, edited by Steve de Gruchy, Nico Koopman, and Syste Strijbos.

Plaatjies-Van Huffel, Mary-Anne E. 2008c. "Die Doleantiekerkreg en die Kerkreg en Kerkregering van die Nederduitse Gereformeerde Sendingkerke en die VGKSA.” PhD thesis, University of Pretoria.

Plaatjies-Van Huffel, Mary-Anne E. 2010. "Response on Anne-Claire Mulder: Empowering Those Who Suffer Domestic Violence: The Necessity of Different Theological Imagery by Human Dignity and the Gift of Mutual Recognition." At the North South Dialogue on Human Dignity in the Context of Domestic Violence: Crossing Boundaries Conference Kampen 18-28 October 2010.

Plaatjies-Van Huffel, Mary-Anne E. 2011a. “The Institutionalization of Christian Women's Organizations: From Docile Recipients to Agents of Change." Studia Historiae Ecclesiasticae 37 (1) (May). http://uir.unisa.ac.za/handle/10500/4616; scholar.sun.ac.za.

Plaatjies-Van Huffel, Mary-Anne E. 2011b. "Control, Secede, Vested Rights and Ecclesiastical Property." Studia Historiae Ecclesiasticae 37 (2) September. http://uir.unisa.ac.za/handle/10500/5126.

Plaatjies-Van Huffel, Mary-Anne E. 2011c. "Patriarchy as Empire: A Theological Reflection." Studia Historiae Ecclesiasticae XXXVII (December Supplement).

Plaatjies-Van Huffel, Mary-Anne E. 2013a. "The URCSA's Engagement on Legal Matters in South Africa.” NGTT 54 (Supplement 4): 101-113. https://doi.org/10.5952/54-0-294.

Plaatjies-Van Huffel, Mary-Anne E. 2013b. "The Belhar Confession: Born in the Struggle against Apartheid in Southern Africa, a Guiding Light for Today." Studia Historiae Ecclesiasticae: 1-11. http://wwwuir.unisa.ac.za/bitstream/handle/10500/9977/.

Plaatjies-Van Huffel, Mary-Anne E. 2013c. "Reading the Belhar Confession as Historical Text." In Reformed Churches in South Africa and the Struggle for Justice: Remembering 1960-1990, edited by R. R. Vosloo and Mary-Anne E. Plaatjies-Van Huffel. Sun Press. https://doi.org/10.18820/9781920689117. 
Plaatjies-Van Huffel, Mary-Anne E. 2013d. "The Search for a Common Understanding with regard to Ecology and Justice in the Uniting Reformed Church in Southern Africa." Studia Historiae Ecclesiasticae XXXIX (2), December.

Plaatjies-Van Huffel, Mary-Anne E. 2013e. "Response on Anne-Claire Mulder's: Empowering Those Who Suffer Domestic Violence: The Necessity of Different Theological Imagery by Human Dignity and the Gift of Mutual Recognition." http://hdl.handle.net/10019.1/91414.

Plaatjies-Van Huffel, Mary-Anne E. 2013f. Sermon for the Family of the late State President Nelson R. Mandela. Sermon at Prayer Meeting at Mandela's Residence in Houghton on 11 December 2013.

Plaatjies-Van Huffel, Mary-Anne E. 2014. "The Relevance of Reformed Church Polity Principles: Revisiting the Concept." In Protestant Church Polity in Changing Contexts, edited by Leo Koffeman and Allan Janssen. LIT Verlag, 31-50.

Plaatjies-Van Huffel, Mary-Anne E. 2015. "A Chronology of the Political and Theological Activity at the University of Western Cape during the Heyday of the Struggle against Apartheid." In Umstrittene Beziehungen Protestantismus zwischen dem südlichen Afrika und Deutschland von den 1930er Jahren bis in die Apartheid Zeit = Contested relations: Protestantism between South Africa and Germany from the 1930s to the Apartheid Era, edited by Hans Lessing, Tilman Dedering, Jürgen Kampmann, and Dirk J. Smit. LIT Verlag.

Plaatjies-Van Huffel, Mary-Anne E. 2017a. "Natural Law in the Reformed Tradition." In Christianity and Natural Law: An Introduction, edited by Norman Doe. Cambridge University Press. University of Cambridge. https://doi.org/10.1017/9781316890615.

Plaatjies-Van Huffel, Mary-Anne E. 2017b. "From Conciliar Ecumenism to Transformative Receptive Ecumenism.” HTS Teologiese Studies/Theological Studies 73 (3), a4353. https://doi.org/10.4102/hts.v73i3.4353.

Plaatjies-Van Huffel, Mary-Anne E. 2017c. “Acceptance, Adoption, Advocacy, Reception and Protestation: A Chronology of the Belhar Confession.” In Belhar Confession. The Embracing Confession of Faith for Church and Society, edited by Mary-Anne E. PlaatjiesVan Huffel and Leepo Modise. Sun Press, 1-96.

Plaatjies-Van Huffel, Mary-Anne E. 2020. "Rethinking the Reciprocity between lex credendi, lex orandi and lex vivendi: As we Believe, so we Worship. As we Believe, so we Live." HTS Teologiese Studies/Theological Studies 76 (1): a5878. https://doi.org/10.4102/hts.v76i1.5878.

Uniting Reformed Church in Southern Africa (URCSA). 1994. Acts of General Synod URCSA, CLF Publishers, Cape Town.

Uniting Reformed Church in Southern Africa (URCSA). 2016. Church Order General Synod, CLF Publishers, Cape Town. 
Urbaniak, J. 2016. "What Makes Christology in Post-apartheid South Africa Engaged and Prophetic? Comparative Study of Koopman and Maluleke." In Theological Disciplines and the (Post)-apartheid Condition: Genealogies and Future Directions, edited by R. Venter. Bloemfontein: University of the Free State. Theological Explorations, Vol. 1, 125155.

Van Marle, K. 2003, "Revisiting the Politics of Post-apartheid Constitutional Interpretation." TSAR (2003).

Van Marle, K. (ed). 2009. Refusal, Transition and Post-apartheid Law. https://doi.org/10.18820/9781920338213.

Voetius, G. 1888. Kerkregtelike Verhandelingen, translated from De Politica Ecclesiastica van Gysbertus Voetius, edited with preface by F. L. Rutgers. Amsterdam: J. A. Wormser. 